\title{
CAMA
}

Centre for Applied Macroeconomic Analysis

\section{Economic Growth and the Transition from Traditional to Modern Energy in Sweden}

\section{CAMA Working Paper 65/2013 September 2013}

\author{
Astrid Kander \\ Department of Economic History, Lund University, Sweden
}

\section{David I. Stern}

Crawford School of Public Policy, ANU and

Centre for Applied Macroeconomic Analysis (CAMA), ANU

\begin{abstract}
We examine the role of substitution from traditional to modern energy carriers and of differential rates of innovation in the use of each of these in Sweden from 1850 to 1950. We use a simple growth model with a nested CES production function and exogenous factor augmenting technological change and carry out a growth accounting decomposition based on the econometric results. Energy and energy augmenting technological change contributed more than a third of the economic growth in this period. Even though the rate of technical change was much larger for modern energy, innovation in the use of traditional energy carriers contributed more to growth between 1850 and 1890, since the cost share of traditional energy was so much larger than that of modern energy in that period. However, after 1890 we find that modern energy contributed much more to economic growth than traditional energy, but increasingly labor augmenting technological change and capital accumulation became the most important drivers of growth in the final decades of the period.
\end{abstract}




\section{Keywords}

\section{JEL Classification}

O13, O41, Q43, N13, N14

\section{Address for correspondence:}

(E) cama.admin@anu.edu.au

The Centre for Applied Macroeconomic Analysis in the Crawford School of Public Policy has been established to build strong links between professional macroeconomists. It provides a forum for quality macroeconomic research and discussion of policy issues between academia, government and the private sector.

The Crawford School of Public Policy is the Australian National University's public policy school, serving and influencing Australia, Asia and the Pacific through advanced policy research, graduate and executive education, and policy impact. 


\title{
Economic Growth and the Transition from Traditional to Modern Energy in Sweden
}

\author{
Astrid Kander \\ Department of Economic History, Lund University, SE-221 00 Lund, SWEDEN. E-mail: \\ astrid.kander@ekh.lu.se
}

David I. Stern

Crawford School of Public Policy, Australian National University, Canberra, ACT 0200, AUSTRALIA. E-mail: david.stern@anu.edu.au

19th September 2013

\begin{abstract}
We examine the role of substitution from traditional to modern energy carriers and of differential rates of innovation in the use of each of these in Sweden from 1850 to 1950 . We use a simple growth model with a nested CES production function and exogenous factor augmenting technological change and carry out a growth accounting decomposition based on the econometric results. Energy and energy augmenting technological change contributed more than a third of the economic growth in this period. Even though the rate of technical change was much larger for modern energy, innovation in the use of traditional energy carriers contributed more to growth between 1850 and 1890, since the cost share of traditional energy was so much larger than that of modern energy in that period. However, after 1890 we find that modern energy contributed much more to economic growth than traditional energy, but increasingly labor augmenting technological change and capital accumulation became the most important drivers of growth in the final decades of the period.
\end{abstract}

JEL Codes: O13, O41, Q43, N13, N14

\section{Acknowledgements:}

We thank the Australian Research Council for support under Discovery grant DP120101088: "Energy Transitions: Past, Present and Future" and VINNOVA: "Sustainable growth, energy and innovations". We also thank Lennart Schön for providing unpublished data for the capital stocks. 


\section{Introduction}

How important was the transition from traditional energy carriers, such as firewood and animal feed, to fossil fuels, initially coal, in fuelling the increase in the rate of economic growth known as the Industrial Revolution? Many energy and ecological economists (e.g. Cleveland et al., 1984; Ayres and Warr, 2005, 2009, Hall et al., 2003; Mayumi, 1991), geographers (e.g. Smil, 1994), as well as many economic historians (e.g. Cipolla, 1962; Wilkinson, 1973; Wrigley, 1988, 2010; Allen, 2009; Kander et al., 2013) argue that innovations in the use of and growth in the quantity of coal played a crucial role in explaining the Industrial Revolution. But some economic historians (e.g. Clark and Jacks, 2007; Kunnas and Myllyntaus 2009) argue, instead, that it was not necessary to expand the use of modern energy such as coal and most growth economists (e.g. Galor, 2011) do not assign any special role to energy in economic growth. ${ }^{1}$ Our key research questions are: What direct effects on growth did the transition to modern energy and the more efficient use of it have compared to the increased efficiency and expansion in the use of traditional energy carriers? Did these effects vary over the course of the transition? We address these questions using historical data from Sweden for the period 1850-1950.

The pre-industrial energy system was plagued by two limitations that restricted population and per capita income growth. The first was that of low power, as there were still no machines to convert heat into motion. This drawback was solved with steam engines and later by internal combustion engines. The second limitation of the pre-industrial energy system was that energy production demanded vast land areas for its production, was very labor intensive, and required extensive transportation from geographically dispersed energy sources (Wrigley, 1962). These limitations were overcome during industrialization by

\footnotetext{
${ }^{1}$ Madsen et al. (2010) did test the role of coal in an endogenous growth model but found that, controlling for patent applications, changes in coal production did not have a significant effect on labor productivity growth in Britain between 1700 and 1915. To us this is not so surprising. First, British coal production is less relevant than coal consumption, since some of it was exported. Second, it is precisely the effect of important innovations such as steam engines or coke-based technologies that led to increased energy and capital used per worker and a surge in labor productivity. So it is possible to attribute these to innovation rather than to increased energy use. Third, as Madsen et al.'s (2010) regression is in first differences, they can only measure the direct short-run impact effect of changes in energy use. By contrast, in this paper, we use modern energy consumption rather than coal production, we distinguish between energy- and labor-augmenting technological change, and we estimate long-run relations between the variables.
} 
coalmines and railways, enabling large amounts of energy to be captured at a single location and be easily transported to urban areas. Still the pre-industrial society was by no means stationary. Some population growth was enabled by agricultural productivity increases and efficiency improvements in charcoal use in iron production as well as stove efficiency increase among households (in cold northern Europe). But such improvements were barely able to offset population growth, so energy use per capita hardly grew (Figure 1). This posed severe limits to income per capita growth in the pre-industrial energy system, and per capita consumption even declined in the $16^{\text {th }}$ century as a result of colder climate and lower agricultural output. Still, it is plausible that increased efficiency of traditional energy may have played a role in growth, since use of the traditional energy carriers did expand and the efficiency with which they were used increased significantly in the 19th Century (Kander et al., 2013).

Economic history provides some qualitative models of the (First) Industrial Revolution, where the shift from an organic economy to one that exploits fossil fuels plays a fundamental role (e.g. Wrigley, 1988, 2010; Pomeranz, 2000; Allen, 2009; Kander et al., 2013). Wrigley (2010) argues that institutional change was an inadequate explanation for the sustained takeoff in economic growth. Instead, he stresses the importance of the transition to fossil fuels that broke the constraints of the organic economy. In the organic economy, the restricted land input meant that in the face of population growth and low rates of technological change, output per capita tended to fall, which is not the case in a constant returns to scale economy. This had been the prime concern of the classical economists Smith, Malthus, and Ricardo. Wrigley makes his case by comparing the Dutch and the English economies. The Netherlands was more modern and advanced than England during the bulk of the early modern period and at the end of the seventeenth century average incomes were higher than in England. But, unlike Britain, the Netherlands did not have access to domestic coal. Instead it relied on peat, which has a much lower energy content per unit weight than coal. Furthermore, Dutch peat resources were restricted and peat production declined after the mid-seventeenth century, so that at the end of the eighteenth century production per capita was lower than a century and a half earlier. Meanwhile, per capita coal consumption in England increased five-fold and England industrialized much faster and overtook the Netherlands in income per capita.

Pomeranz (2000) explained the economic advance of Europe relative to East Asia during the $19^{\text {th }}$ century as the result of a greatly increased resource base, by using domestically mined 
coal, and land-based resources such as food and fibers extracted from the colonies. In other words Pomeranz considers coal and colonies to be the two important ingredients in the successful English industrial revolution, which allowed the English to break loose from their land constraints and access "ghost acres".

Allen (2009) places innovations in exploiting coal at the center of his explanation of why the industrial revolution occurred in Britain. Compared to the other advanced European economies of the time (the Netherlands and Belgium) and the advanced economy in the East - China - England stands out as an exception in two ways: coal was relatively cheap there and labor costs were higher than elsewhere. Therefore, it was profitable to substitute coal-fuelled machines for labor in Britain, even when those machines were inefficient and consumed large amounts of coal. Though he also stresses that many technological innovations were required in order to use coal effectively in new applications ranging from domestic heating and cooking to iron smelting.

Kander et al. (2013) take a big step forward in validating Wrigley's idea that the breaking the two constraints of the organic economy - those of land and low power - was what spurred industrialization. They present the first detailed figures on energy consumption for much of Europe reaching back over several centuries and including traditional as well as modern energy carriers. These show that, although the path of modern economic development has vastly increased our energy use, it has not been a story of smoothly increasing energy consumption. Energy history has been profoundly shaped by a series of revolutions, closely associated with new 'carriers' such as coal, oil and electricity and the new technology to exploit them, from steam engines and motor vehicles to ICT.

The traditional energy economy of medieval and early modern Europe was marked by stable or falling per capita energy consumption. The First Industrial Revolution founded on coal and steam engines, redrew the economic, social, and geopolitical map of Europe and the world. A second industrial revolution continued this energy expansion and social transformation through the use of oil and electricity. The Third Industrial Revolution led to a stabilization in per capita energy use after 1970.

Capital deepening (more physical capital per worker) was an important ingredient in the first industrial revolution. Kander et al. (2013) demonstrates that the reduced costs of producing 
coke-iron were essential to cheap machinery production and capital-deepening industrialization and that continued innovation that improved energy efficiency and reductions in the cost of transporting coal with steam-powered ships and trains, eventually made coal-using technologies profitable in other countries too and cheap iron and machinery diffused abroad, which spurred the diffusion of industrialization to other countries than England. Berg (1978) similarly argues that innovation that allowed coal to be used in novel ways drove the shift to coal in the United States far more than any scarcity of firewood.

The rich, new energy datasets provided by Kander et al. (2013) allow for a more convincing argument regarding the role of energy in economic growth. However, their analysis is limited to verbal discussion of tables and graphs of the times series (firewood, coal, oil etc) and ratios of the time series, such as energy intensity, which they decompose into structural and technical change. In this paper, we aim to advance the argument one step further by for the first time quantitatively modeling the role of both traditional and modern energy in Swedish industrialization.

We use Sweden as a case study partly because of good data availability. Though long-run historical energy use data are now available for several countries in Europe and North America (Kander, 2002; Malanima, 2006; Gales et al., 2007; Warde, 2007; Henriques, 2011; Kander et al. 2013), long run consistent national energy price series are so far only available for Sweden (Kander, 2002). ${ }^{2}$ Also, the transition to coal took place very early in England and data for that period are naturally scarcer and less certain. For instance, there are fairly reliable GDP figures for Sweden starting in 1800 (Krantz and Schön 2007).

Sweden was a late industrializer and energy use per capita followed a path very different to that of England and more similar to Europe as whole (Figure 2). Both Swedish and English energy consumption were well above the European average in 1800, at around $50 \mathrm{GJ}$ per capita per year, but there was a tremendous increase in per capita energy use England over the $19^{\text {th }}$ century, while in Sweden per capita energy use actually declined somewhat until the 1890s. From then on, energy use grew very strongly in Sweden until 1970 while in England there was a fall in energy consumption per capita in the first decades of the $20^{\text {th }}$ century and

\footnotetext{
${ }^{2}$ Long run time series for prices exist for England but they are not representative of the country as a whole (Fouquet, 2008). Energy prices varied greatly depending on whether a location was close to coal and wood resources or not.
} 
then a milder increase, so that both countries ended at approximately the same level around 1970. Figure 3 compares the transition to coal in various European countries. We see that England was the clear leader followed by Germany and the Netherlands. Sweden was relatively late in its transition to coal following a similar path to Spain.

Sweden was, therefore, still almost entirely dependent on traditional sources of energy in the early $19^{\text {th }}$ century (mainly firewood and fodder for draft animals) while the transition to coal continued deep into the $20^{\text {th }}$ century (Figure 4 ). As a result, we can observe the entire energy transition from traditional energy carriers to coal in a more recent period than the transition took place in England. There is also reason to expect a clearer connection between industrialization and the transition to modern energy carriers in Sweden than in England. In England coal was already used on a large scale long before the introduction of steam engines and industrialization, simply to replace firewood for heating purposes (Warde, 2007). In Sweden, which has only a very little domestic coal located in the western part of Scania, coal use had a much clearer connection to the Industrial Revolution.

We aim at a more formal quantification of the ideas of many economic historians that the transition to modern energy was crucial for driving economic growth during the Industrial Revolution. In a previous paper (Stern and Kander, 2012), we extended a conventional Solow (1956) growth model to include energy and biased technological change, but we did not distinguish between modern and traditional energy. With this model, we showed that the expansion of energy use, increases in energy quality, ${ }^{3}$ and energy augmenting technological change explained much of the growth in Sweden up till 1950. Thereafter, in the period covering the Third Industrial Revolution, labor augmenting technological change became dominant in explaining economic growth. This previous result provides one rationale for restricting our analysis to the period 1850-1950. Another reason is that the transition to coal in Sweden took place from 1850 to 1950 . Oil use was quite low until the very end of the period after which it surged. Extending the period of analysis from the more conventional economic history endpoint of 1913 up until 1950 has another advantage: the extended period contains two World Wars, when coal imports were severely restricted in Sweden and the

\footnotetext{
${ }^{3}$ Energy carriers vary in quality, which reflects their productivity, flexibility, and other properties (Stern, 2010). Generally primary electricity is seen as the highest quality energy source and coal, wood, and other combustible biomass as the lowest, with oil, gas, and animal power at an intermediate level.
} 
government initiated attempts to replace these lost imports with firewood and hydropower (Kaijser and Kander, 2013). These world wars should provide much information on the substitution possibilities.

Some caveats in our modeling should be mentioned from the very start. We model the economy as a single sector and treat technological change as exogenous. Therefore, we cannot model the specific effects of particular capital goods such as railways on urban agglomeration and the consequent effects on growth. However, our model is dynamic energy-augmenting innovations increase the economy-wide total factor productivity (TFP) and as in the standard Solow growth model, TFP growth induces capital accumulation and deepening. We also assume that quantities of traditional energy are exogenous, while energy prices are endogenous. While this assumption is valid for traditional energy, which was produced within Sweden, coal was mostly imported. In 1800 domestic coal production and imports were of equal (very small) size, but by 1850 the quantity of imported coal was already twice as large as domestic production and by 1860 ten times larger, a ratio that stayed more or less the same over the next hundred years, except for during the World Wars, when domestic production was increased. On the other hand, the behavior of prices in the World Wars suggests that the coal price was not just determined internationally.

The next section of the paper describes our model. This is an extension of Stern and Kander (2012) to allow for multiple energy inputs and to differentiate between technological change that improves the efficiency of the use of modern and traditional energy carriers at different rates. The third section explains the sources for our Swedish data set. This is followed in the fourth section by a discussion of the data in the context of Swedish economic history. In the fifth section of the paper, we present the results including estimates of the rates of factor augmenting technological change and the interfuel and interfactor (between capital-labor and energy) elasticities of substitution. These results are then used to carry out a growth accounting exercise to determine the importance of the various factors in economic growth over time. Our key new finding is that the contribution of modern energy-augmenting technological change was small in comparison to traditional-fuel augmenting technological change in the late $19^{\text {th }}$ century. This is because a small sector that is highly innovative may not affect overall GDP growth very much, a fact that has caused much discussion in economic history of the appropriateness of the term "Industrial Revolution" referring to a period in time when the modern sectors were still very small and could not logically have 
much impact on overall GDP growth (Temin 1997; Harley and Crafts 2000). The final section of the paper provides some discussion and our main conclusions.

\section{Model and Methods}

We extend Stern and Kander's (2012) model of the role of energy in economic growth by disaggregating the energy input into traditional and modern energy types and allowing for traditional or modern energy augmenting technological change. In Stern and Kander's model, when the elasticity of substitution between energy and capital and labor is less than unity and effective energy is scarce, energy availability strongly constrains economic output and the economy remains trapped in pre-industrial stagnation. Labor-augmenting technological change and capital accumulation have little effect on growth and the optimal capital stock is small. As effective energy becomes more and more abundant the model behaves more and more like the conventional Solow (1956) model, which characterizes the modern growth regime.

However, the Industrial Revolution was characterized not just by the increased availability and quality of energy and energy augmenting innovations. Rather, there was a differential expansion of use of the modern energy carriers, first coal and then oil, primary electricity, and natural gas as well as the innovations that found new ways of using these fuels (Gales et al. 2007, Allen, 2009). Also, the data from Sweden (Kander, 2002), Spain (Rubio 2005; Iriarte-Goñi and Ayuda, 2008) and Britain (Warde, 2007; Iriarte-Goñi and Ayuda, 2012) show that there was continued expansion of traditional fuels in absolute terms, although the share of traditional fuels was falling. Additionally, key innovations such as improved boilers and stoves and better insulation augmented the effective supply of traditional energy in the $19^{\text {th }}$ century, and innovations in agriculture reduced the per hectare need for draft animals, which also augmented the effective supply of muscle energy (Kander, 2002; Kander and Warde, 2011).

We model the production relations using the following nested constant elasticity of substitution (CES) production function:

$$
Y_{t}=\gamma_{Y}\left(\left(1-\gamma_{E}\right)\left(A_{L t}^{\beta} L_{t}^{\beta} K_{t}^{1-\beta}\right)^{\phi}+\gamma_{E}\left(\gamma_{B}\left(A_{B t} Q_{B t} B_{t}\right)^{\omega}+\left(1-\gamma_{B}\right)\left(A_{M t} Q_{M t} M_{t}\right)^{\omega}\right)^{\frac{\phi}{\omega}}\right)^{\frac{1}{\phi}}
$$


$\phi=\frac{\sigma-1}{\sigma}, \omega=\frac{\eta-1}{\eta}$

where $Y$ is gross output, $B$ is traditional biomass-based energy including fuel-wood and muscle power derived from animal feed, and $M$ is modern energy (coal, oil, natural gas, and primary electricity). Each of these is associated with a augmentation and quality indices $-A_{B}$ and $A_{M}$ and $Q_{B}$ and $Q_{M}$ respectively, while $A_{L}$ is the augmentation index of labor. The elasticity of substitution between the two types of fuels is $\eta$ and between the energy and value added aggregates is $\sigma$. As the share of modern fuels is initially very small and coal and firewood could often be used for the same applications, it is likely that $\eta>1$ so that neither fuel is essential. Based on our previous results, we expect that $\sigma<1$. The $\gamma_{i}$ 's are parameters reflecting the relative contributions of energy and capital-labor to gross output and a scaling factor.

We assume that the augmentation indices follow exponential trends with a linearly changing rate of augmentation, so that:

$$
A_{i t}=\exp \left(\tau_{i 1} t+\tau_{i 2} t^{2}\right)
$$

where, $\mathrm{t}$, is a linear time trend. Exogenous technological change allows us to attribute growth to technological change rather than some underlying factors. Also, it may be a reasonable approximation in Sweden, which largely was a follower economy in the process of industrialization. The new prime movers such as the steam engine, internal combustion engine and electric generator/motor all came from abroad. Likewise the Haber-Bosch method for producing fertilizers, which contributed enormously to land productivity, came from Germany (Smil, 2005, 2010). Of course, there were also important local innovations such as more efficient domestic stoves (Cronstedt and Wrede in the $18^{\text {th }}$ century) or Wenström's contributions to the alternating currency motor system in Sweden at the same time as this was done in other countries by other innovators, for instance by Ferrari in Italy and Tesla in Yugoslavia (Hughes 1983), but the radical innovations that really spurred growth came from outside Sweden. A more elaborate directed technical change model (Acemoglu, 2002; Gancia and Zilbotti, 2005) is needed to model the factors driving differential innovation in the use of biomass and fossil fuels as discussed by Allen (2009). However, even with our simple model we can still measure how important innovation in the use of each fuel appears to have been. 
The use of gross output rather than just value added (GDP) merits some discussion. When modeling the effects of intermediate inputs on growth, for accounting consistency we need to use a measure of output that does not net out the marginal contributions of the intermediate inputs so that the total value of output is equal to the total value of inputs (O'Mahony and Timmer, 2009; Berndt et al., 1993). Following Berndt et al. (1993), we add the value of energy to the value of the GDP. ${ }^{4}$

The CES production function imposes the assumption that the elasticities of substitution are constant throughout the century of data that we investigate. This may seem a bit unrealistic. Substitution possibilities between modern and traditional energy did presumably decline when oil and electricity gained larger roles in the energy system, but for the period up until 1950 coal was so dominant among the modern fuels that this assumption does not seem unreasonable. The advantage of the CES production function over more flexible functional forms such as the translog function is that it is very structured and has a small number of parameters to estimate. While we lose flexibility compared to the translog, we ensure that the results conform to economic theory. For example, we found using a translog function that some input demand elasticities were positive, so that higher input prices would increase demand for those factors, which is clearly not in accord with economic theory. There seem to be rather strict limits to how much flexibility can be modeled using such historical data series and we decided it was better to model some of the main features more reliably or believably than to attempt to model many features of the data less reliably.

Obviously, equation (1) is simply a production function rather than a complete model of growth, but we do not need a full growth model for either the econometric estimation or growth accounting exercises presented in this paper. In addition to Stern and Kander (2012), related growth models using CES production functions with energy or land inputs have been

\footnotetext{
${ }^{4}$ The following highly simplified example explains the rationale for this. Assume that there are final goods and domestic energy sectors and that final production uses domestic energy as well as imported energy in addition to the primary inputs (labor and capital), while domestic energy production only uses primary factors. Then GDP in the final output sector is given by: $G_{F}=Y_{F}-p_{E D} E_{D}-p_{E I} E_{I}$ and in the domestic energy sector $G_{E}=p_{E D} E_{D}=Y_{E}$ where the $F$ subscript indicates the final output sector, $G$ is GDP, the $D$ subscript indicates domestic energy $(E)$ production and $I$ imported energy. Then gross output is given by: $Y=Y_{F}+Y_{E}=G_{E}+G_{F}+p_{E D} E_{D}+p_{E I} E_{I}$, which is GDP plus the value of energy. Furthermore, large amounts of traditional energy (firewood) were not sold on the market at all in Sweden, but collected for domestic use. The imputed value of this production should be added to the output of the economy.
} 
proposed by Saunders (1992), Petith (2008), and Hassler et al. (2012). Our model is also somewhat similar to Fröling's (2011) unified growth model. But we estimate our model econometrically using time series data, while Fröling (2011) carries out a simulation of her theoretical model. She assumes that energy services are a constant elasticity of substitution (CES) aggregate of coal and biomass with an elasticity of substitution of 3, which is close to our empirical estimate (4.4) Her model has two stocks of knowledge one of which enhances TFP in the production of final output and the other enhances the productivity of coal in producing energy services. She assumes that knowledge cannot augment the productivity of biomass. By contrast, our model allows technological change to augment biomass and we actually find that augmentation of traditional energy was substantial.

Estimating the model parameters using (1) alone is theoretically possible due to the nonlinearity of the equation but the coefficients of the time trends will be very poorly identified and better estimates can be obtained by using multiple estimation equations, which provide more information (Leon-Ledesma et al., 2010). We use (1) together with the first order conditions under the assumption of perfect competition in the hiring of inputs to estimate the model parameters. ${ }^{5}$ We impose a fixed value on $\beta$ when estimating the remaining parameters. Edvinsson (2005) provides gross profit ratio data for 1850-2000. Multiplying this rate by the capital stock series and dividing by GDP shows that the capital share has fluctuated around a mean of $23 \%$ of GDP from 1850 to 1950 . We, therefore, treat $\beta$ as a known parameter with a value of 0.77 . We, therefore, use the conditions for efficient employment of labor, traditional fuels, and modern energy. Because the cost shares are bounded between zero and unity, we use the logs of the ratios of the cost shares because we expect these to be more normally distributed (Kim, 1992; Aitchison and Egozcue, 2005). The ratios we use are the ratio of labor costs to traditional energy costs and the ratio of traditional to modern energy carrier costs:

$\ln \left(\frac{S_{L t}}{S_{B t}}\right)=\ln \left(\frac{\beta\left(1-\gamma_{E}\right)}{\gamma_{E} \gamma_{B}}\right)+\phi\left(\begin{array}{l}\left(\frac{1}{\omega}-\phi\right) \ln \left(g_{t}\right)-\left(\ln A_{B t}+\ln Q_{B t}+\ln B_{t}\right)+ \\ \beta\left(\ln A_{L t}+\ln L_{t}\right)+(1-\beta) \ln K_{t}\end{array}\right)+u_{L t}$

\footnotetext{
${ }^{5}$ Under monopsony input prices are not equal to the values of marginal products. But as long as input prices change by the same percentage as the relevant marginal products change then the input price ratio should change by the same percentage as the marginal product ratio changes. Therefore, estimates of elasticities of substitution and technical change biases should be unaffected by violation of this assumption.
} 


$$
\begin{aligned}
& \ln \frac{S_{B t}}{S_{M t}}=\ln \left(\frac{\gamma_{B}}{1-\gamma_{B}}\right)+\omega\left(\ln A_{B t}-\ln A_{M t}+\ln B_{t}-\ln M_{t}+\ln Q_{B t}-\ln Q_{M t}\right)+u_{B t} \\
& g_{t}=\gamma_{B}\left(A_{B t} Q_{B t} B_{t}\right)^{\omega}+\left(1-\gamma_{B}\right)\left(A_{M t} Q_{M t} M_{t}\right)^{\omega}
\end{aligned}
$$

where the $S_{i}$ are shares in costs and the $u_{i t}$ are random error terms. These two equations are estimated jointly with the following logarithmic transformation of (1):

$$
\ln Y_{t}=\ln \gamma_{Y}+\frac{1}{\phi} \ln \left(\left(1-\gamma_{E}\right)\left(A_{L t}^{\beta} L_{t}^{\beta} K_{t}^{1-\beta}\right)^{\phi}+\gamma_{E}\left(\gamma_{B}\left(A_{B t} Q_{B t} B_{t}\right)^{\omega}+\left(1-\gamma_{B}\right)\left(A_{M t} Q_{M t} M_{t}\right)^{\omega}\right)^{\frac{\phi}{\omega}}\right)+u_{Y t}
$$

using non-linear least squares. We use the logarithm of gross output due to the high level of heteroskedasticity in the untransformed series. We use the Newey and West (1987) approach to computing the covariance matrix of the coefficients with five correlated lags. We normalize the values of the inputs, quality factors, output, and the factor augmentation trends to unity in 1900, which is the midpoint of the sample, which greatly aids in finding the optimal parameter estimates (Leon-Ledesma et al., 2010).

It is safe to assume that all the key time series in the model have stochastic trends and so we do not engage in formal testing of that hypothesis. However, it is necessary to test that the residuals are stationary in order to ensure that the estimated relationships are statistically valid and not spurious regressions. We test that the residuals are stationary using the Choi and Saikkonen (2010) non-linear cointegration test. Their test is based on the KPSS test (Kwiatkowski et al., 1992) and, therefore, the null hypothesis is that the residuals are stationary. Hong and Wagner (2008) provide critical values.

We use our model estimates to decompose the contributions of the factors of production and types of technological change to GDP growth in Sweden. GDP, $G$, can be modeled as follows:

$$
G_{t}=Y\left(K_{t}, L_{t}, B_{t}, M_{t}, t\right)-\frac{\partial Y_{t}}{\partial B_{t}}\left(K_{t}, L_{t}, B_{t}, M_{t}, t\right) B_{t}-\frac{\partial Y_{t}}{\partial M_{t}}\left(K_{t}, L_{t}, B_{t}, M_{t}, t\right) M_{t}
$$


where the first term on the RHS is gross output, produced according to (1) and the other two terms net out the contributions of the two types of energy. Their marginal products are functions of the various inputs and time. In order to obtain a growth accounting equation for GDP, we take the total derivative of (6):

$$
\frac{d G_{t}}{d t}=\sum \frac{\partial G_{t}}{\partial X_{i t}} \frac{d X_{i t}}{d t}
$$

where the $X_{i}$ are the following factors: $K, L, A_{L}, B, Q_{B}, A_{B}, M, Q_{M}, A_{M}$. Dividing both sides of (7) by $G$, multiplying and dividing each factor, $X_{i}$, by itself, and approximating using natural logarithms and discrete changes we obtain:

$$
\Delta \ln G_{t}=\sum \frac{\partial \ln G_{t}}{\partial \ln X_{i t}} \Delta \ln X_{i t}
$$

We use (6) and (1) to compute the elasticities numerically. The contribution of each driver depends on its relevant GDP elasticity, which changes over time. The effect of the driver on changing the output elasticities over time also affects the rate of economic growth. As a result, a major driver of growth in our model is the reduction in the cost share of energy, which allows more resources to be directed towards producing final output.

These growth accounting results depend on the assumption that energy use causes growth and not the other way round. In reality there are complex relations between energy use and growth, and the Granger-causality results are mixed (Bruns et al., in press). Using the same dataset as we use here, Stern and Enflo (2013) find that quality adjusted energy use causes growth. However, they also find that, controlling for energy prices, energy use does not directly cause GDP. Instead, GDP causes energy use, energy prices cause energy use, and the energy price index also appears to be endogenous, though not when only post-1950 data are used. This suggests that modern energy prices are exogenous and should be treated as a driver of growth while quantities of traditional energy are more exogenous. Therefore, the quantity and quality of modern energy should be seen as merely proximate rather than ultimate causes of growth. 


\section{Data Sources}

We compiled an annual data set for Sweden from 1850 to 1950 as follows. For the modern energy carriers - coal, oil, natural gas, and electricity - there are reliable historical statistical sources, such as import and production data. For the quantities of traditional fuels such as fuel-wood and fodder this is not the case, especially in the $19^{\text {th }}$ century, and so estimates must be made. This means that, to some degree, our results are determined by our assumptions, but this is the case for most historical estimates, such as those of GDP itself. We use the estimates developed by Kander (2002) who also tabulates the quantity and price series for the modern energy carriers. The reconstruction was relatively straightforward for draft animals, since there are good data on the number of horses and oxen (Kander and Warde, 2011). The firewood estimate was based on a "demand-side" analysis, which used data on the population size, geographical dispersion of population between the cold north and warmer south, and urbanization rates, together with assumptions about the efficiency of stoves and the number of heated rooms to model trends in per capita firewood consumption backwards from an actual household survey in the 1920s. There was a major breakthrough with the introduction of the Cronstedt and Wrede chimney with vertical smoke channels, invented in the 1760s in Sweden and the efficiency of stoves increased from $10 \%$ in the mid 1760 s to $80 \%$ at the end of the $19^{\text {th }}$ century. Kander (2002) assumed that every time a chimney needed replacement (usually every 30-40 years) it was built with this new technology. Likewise the number of draft animals is available in historical statistics, but the size evolution and number of workdays for animals were estimated based on certain assumptions (Kander and Warde, 2009). Improvements in the efficiency of the Swedish iron industry's charcoal production are also well researched and documented (Arpi, 1951; Schön, 1992). Nonetheless, these assumptions represent an important caveat in interpreting our model results. We cannot for instance draw the conclusion based on our model that traditional fuel-augmenting technological change was strong in the $19^{\text {th }}$ century, because this would be circular reasoning, since we already knew this and it was built into our data reconstructions of firewood consumption. But we can examine the relative rates of modern and traditional fuelaugmenting technological change given our assumptions and the relative contribution of each to economic growth.

Firewood prices per Joule of energy are sensitive to assumptions of how much energy a particular amount of wood contained as historical prices refer to volumes or weights rather than energy equivalents, so the water content of the wood plays a large role in determining 
the actual energy content. We used the lower of the two firewood prices in Kander (2002). Muscle energy is calculated as the amount of energy in the fodder consumed by animals. The price of muscle energy is based on barley. We aggregated the various energy inputs using both simple addition of heat units and using chain Fisher indexation, which accounts for the effect of shifts in the mix of fuels used on the effective energy services provided. Division of the volume index by the heat equivalent index gives the aggregate energy quality. All data are for primary energy use. This means that only primary electricity - that not generated using carbon based fuels like wood or coal - is included in the quantity of electricity. Total use of electricity is greater than these data indicate, especially in the late $19^{\text {th }}$ century and early $20^{\text {th }}$ century, when a large fraction of the electricity used was generated using fuels. In $188580 \%$ of electricity was generated thermally, but by 1910 this had declined to $30 \%$, with the remained being provided by hydropower, and included in our primary electricity variable (Kander, 2002).

The GDP data comes from the national historical accounts for Sweden (Krantz and Schön, 2007). The labor series is from the same Historical National Accounts (number of employees). The capital stock data has not yet been published, but was kindly provided to us by Lennart Schön. It is based on the investment series that are part of the published Historical National Accounts. The method for turning this into a capital stock is the usual perpetual inventory method using straight-line depreciation of buildings over 50 years and of machinery over 25 years. In other words a building investment loses $2 \%$ of its original value every year, while machinery investment loses 4\%. As mentioned above, we used Edvinsson's (2005) profit series to estimate the share of labor.

\section{Development of Key Factors and Swedish Economic History}

Table 1 presents the level of several key variables at 20 year intervals and Table 2 their growth rates. Traditional energy consists of fuelwood and draft animal muscle energy, and modern energy consists of coal, oil and primary electricity. Sweden was a country that was rich in traditional natural resources (iron ore, wood, and rivers), but poorly endowed with coal and completely without any oil. It was also poorly endowed with capital and had excess labor. Large flows of emigrants went from Sweden to the US after 1860 and capital was imported from the more advanced west European countries, so there was a rapid build-up of the capital stock in relation to labor, as is evident from Table 2. We see that capital per worker grew by more than $3 \%$ per year $1850-1890$, faster than in the period after 1890 . Still, 
the level of capital stock to GDP was substantially lower than the 3:1 ratio proposed by Kaldor as a stylized fact, throughout our period (Table 1). The capital stock was actually smaller than the GDP up until 1870, when it was equal, and after this it increased relative to GDP, but it took Sweden until 2000 for it to catch-up in capital investments and reach the 3:1 level, which had been the case for England ever since the late $19^{\text {th }}$ century (Kander et al., 2013).

The big spurt in Swedish economic growth came from the 1890s onwards though modern growth started in Sweden around 1850 with annual rates of per capita growth of 1-1.5 per cent (Table 2). Before that the annual growth rate was only 0.5 percent per capita. The period 1850-1890 was a period of largely export-led growth; with oats, timber, and iron being the major exports. Butter was another rapidly growing export commodity from the $1880 \mathrm{~s}$. Agriculture remained the dominant sector and simple industrial production based on fuelwood largely took place in the countryside. There was a continued reliance on traditional sources of energy, in a period when other countries had shifted to modern energy carriers. Steam-saws were driven by fuelwood for instance and charcoal was the dominant fuel in the steel industry in Sweden in the period 1850-1890. Only after 1890 did some Swedish steel producers start to use coke as charcoal became increasingly expensive relative to iron ore. This stimulated efficiency improvements both in iron making (i.e. adoption of the Lancashire steel method which reduced charcoal use by $45 \%$ ) and charcoal distribution by railroads and canals (Geijerstam and Nisser 2011).

This means that the traditional energy carriers were still very dominant in the economy in this period (Table 1). In 1870 traditional energy use was 30 GJ per capita, while coal use was only 3 GJ. Total coal use was 13.1 PJ in 1870. 4.8 PJ of this was used for trains and ships, 2 PJ was used in industry (including gas works), 1 PJ was used in agriculture for the about 900 steam traction engines in the country, and the remaining 5.2 PJ was used by households, especially in cities like Malmö, where the surrounding land had been cleared of forests (Kander, 2002).

Crop failures in the 1860s, demand for labor in America, and cheaper transport led to large flows of emigrants to North America. Together with increased capital imports from the early industrializers of Western Europe, Swedish emigration changed relative factor costs quite dramatically: labor became relatively more expensive and capital became cheaper. This 
changed the nature of industrialization in the next phase of development, after 1890 (Schön, 2012).

From the 1890s Swedish industrialization became more domestically oriented, with fastgrowing industries such as manufacturing, telecommunications, banking and railways. Manufacturing now took place more in urban areas and using the new flexible prime mover the steam engine - and coal consumption increased rapidly. Modern energy use per capita was equal to traditional energy use per capita in 1910 and by 1950 was almost four times as large (Table 1). Coal consumption made up the bulk of modern energy use. In 1913, 47 PJ of coal was consumed in industry, but only 1 PJ of oil and 5 PJ of electricity. Railways were driven by steam and not yet electrified; so another $51 \mathrm{PJ}$ of coal was used for railways and ships (Kander, 2002). The innovation of electric arc furnaces came after 1900, which meant that Sweden could again rely partly on its domestic energy sources for steel production, this time hydropower. But electrically produced steel only amounted to some $20 \%$ of steel production in the 1930s and 1940s. The remainder was smelted using coal and coke (Geijerstam and Nisser, 2011). Exports were still important for the economy, but the composition shifted. Steel exports grew only slowly, due to much harder international competition, while exports of ore increased much faster, and paper and pulp exports grew substantially, while exports of sawn wood products decreased in relative importance. Also manufacturing products such as machines and tools experienced a break-through in exports around 1910. Sweden transformed from a backward country to a leading industrial country in terms of growth rates (Schön, 2012). Not participating in the two world wars meant that Sweden had higher growth rates than the European average between 1910 and 1950. This was the period of break-through for the electric motor in industry, and when coal imports were cut during the World Wars Swedish electrification based on hydropower took a big leap forward.

Figure 4 shows the shares of traditional and modern energy in total energy in terms of heat. Until around 1860 , coal, the only modern energy carrier in the early $19^{\text {th }}$ century, was a very small fraction of total energy use. Its share increased rapidly after that date. The two World Wars both resulted in shortages in the supply of fossil fuels and temporary surges in the share of traditional energy carriers. Figure 5 presents the cost shares of the two energy aggregates in the total cost of energy. The picture is rather similar to Figure 4 but coal's cost share in the mid $19^{\text {th }}$ century is even smaller than its heat share. This is because the price of animal 
power, which constituted around $15 \%$ of traditional energy by Joules, was much higher than that of both fuel-wood and coal. In the $20^{\text {th }}$ century, the disruption due to the $1^{\text {st }}$ World War is barely noticeable in the cost share data and that due to the $2^{\text {nd }}$ World War much less pronounced than in the heat share data. This is because of the rise in the price of the fossil fuels in these periods that offset their decline in quantity. Figure 6 shows the prices of traditional and modern energy sources in terms of heat units and quality-adjusted energy. The price of a Joule of traditional energy gradually declines over time. The price of modern energy is much more volatile, generally rising over time with sharp peaks associated with the two World Wars. Adjusting these series for the change in the mix of energy carriers over time by using the quality-adjusted price indices, the price of a unit of modern energy declined over time, while the price of a unit of traditional energy was fairly constant.

\section{Results}

Table 3 presents the parameter estimates and the Choi and Saikkonen (2010) cointegration statistics that test the null of stationary residuals. The null of cointegration cannot be rejected for any of the equations, which means that we can consider the regression equations to be statistically valid. The estimate of $\omega$ implies that the elasticity of substitution between traditional and modern energy is 4.4. As expected this is greater than unity, because all traditional energy carriers can be replaced by modern ones. ${ }^{6}$ The implied elasticity of substitution between capital-labor and the energy aggregate is 0.65 , which is approximately the same as that found by Stern and Kander (2012).

The rates of augmentation of the inputs vary over time with the value of $\tau_{i 1}$ indicating the estimated rate of augmentation in 1900, which is the point of normalization. For modern fuels this rate is $2.4 \%$ p.a., while traditional fuels were augmented at $1.4 \%$, and the annual augmentation rate of labor was $1.0 \%$. The rate of augmentation of labor increases over time while that of the two fuels decreases. This makes sense when we consider the effects of the second industrial revolution, where technological progress was increasingly driven by people with a formal scientific training (Mokyr, 1999). In addition, the workforce was increasingly

\footnotetext{
${ }^{6}$ The reverse is not necessarily true. In many applications, oil and electricity cannot be replaced by traditional fuels. However, electricity can be generated using biomass and modern biofuels can replace oil.
} 
well educated as well as trained on the job. The new technology required more skilled workers relative to un-skilled (Goldin and Katz, 2008).

When the elasticity of substitution between two inputs is less (greater) than unity, the cost share of the input whose effective units grow at a faster rate tends to decline (increase) and vice versa. So the cost share of energy has tended to decline (Stern and Kander, 2012), but the cost share of modern fuels in total energy costs has tended to increase.

Table 4 presents the results of the growth accounting decomposition in terms of contributions to average annual growth in GDP in percentage points over 20 year intervals as well as over the entire century from 1850 to 1950 . The key results are that in the early decades traditional energy augmenting technological change contributed the most to economic growth while in the later decades modern energy augmenting technological change became the most important driver. Increasing quantity and quality of modern energy contributed more over time but made little contribution in the first few decades. The quantities of capital and labor made consistent medium sized contributions over time. These results are fully consistent with Stern and Kander (2012) who found that energy augmenting technical change played its greatest role in the second half of the $19^{\text {th }}$ century, while the quantities and quality of energy were more important for growth in the early $20^{\text {th }}$ century, and labor augmenting technical change became slowly more and more important over time.

The contributions of each factor are, as explained above, a result of the interaction of the rate of change of each factor and its GDP elasticity. The GDP elasticities are closely but not exactly related to the cost shares of the relevant factors. So labor and labor augmenting technological change have a common elasticity, which increased from 0.47 in 1850 to 0.62 in 1950. The elasticity of the three traditional energy factors declines from 0.39 to 0.02 and that of the three modern factors increases from 0.002 to 0.18 over the same period. The capital elasticity increases from 0.14 to 0.18 . Therefore, it is not surprising that modern energy related factors had little impact in the first few decades while traditional energy had a large impact. The growth accounting approach, therefore, provides a conservative estimate of the contribution of modern energy augmenting technological change to growth. These innovations increased the marginal product of energy and, therefore, the contributions to growth of the increase in the quantity of quality adjusted modern energy in the $20^{\text {th }}$ Century were much larger than it otherwise would have been. But these contributions are attributed to 
increases in quantity and quality and not to the earlier innovations that initially had little impact but took time to diffuse (David, 1990).

Our model predicts a gradually accelerating rate of growth from $2.24 \%$ p.a. in $1850-1870$ to $3.13 \%$ p.a. in 1930-1950. Though the average residual over the hundred years is zero the model over-predicts the rate of growth in 1870-1890 and under-predicts it in 1890-1910. So it seems that in reality the rates of technological change followed more complex paths than our simple assumption of a slowing or increasing rate of change for each factor.

\section{Discussion and Conclusions}

Our analysis shows that both modern and traditional energy played important roles in economic growth in Sweden between 1850 and 1950. Our results for the relative importance of energy versus labor and capital largely conform with our previous work (Stern and Kander, 2012). Labor augmentation becomes more important over time, but energy plays a fundamental role in growth all the way until 1950.

The growth accounting exercise shows that overall $1.01 \%$ of the $2.67 \%$ annual growth between 1850 and 1950 was due to energy and energy augmenting technical change, Modern energy accounted for $0.55 \%$ growth p.a. and traditional for $0.46 \%$, so modern energy was somewhat more important overall. While the rate of modern energy augmenting technological change was much faster, the cost share of traditional energy was so large in Sweden in the $19^{\text {th }}$ century that the contribution to growth was actually lower from innovation in using modern energy than from innovation in using traditional energy. The contribution from modern energy augmenting technical change was only $0.02 \%$ p.a., while the contribution from traditional energy augmenting technical change was $0.42 \%$. This thus supports the argument of Kunnas and Myllyntaus (2009) that industrialization in the Nordic countries relied to a large degree on traditional energy, but it still shows that increases in the quantity and quality of modern energy were more important. It also supports the ideas of Wrigley (2010) and Kander et al. (2013) that organic economies were innovative and successfully tried to increase productivity. But we see that in terms of quantities alone the expansion of modern energy drove growth much more than traditional energy: 0.28\% p.a. was contributed by expansion of modern energy use and only $0.09 \%$ by expansion of traditional energy use. So, the results support the idea that breaking the land constraints of organic economies and accessing to fossil fuels was indeed important for modern economic 
growth. Sweden could not simply have expanded its economy based on firewood. For instance, it seems safe to conclude that Swedish steel production would have been completely outcompeted in the period from 1900 to 1950 without a transition to cheaper coal (and some electric arc furnace steel). Charcoal-based iron was then far too expensive.

On top of this, the increase in the quality of modern energy, due to the beginnings of electrification and the introduction of oil, contributed $0.25 \%$ p.a., at the same time as traditional energy quality declined due to a reduced contribution from animal power. The view of Clark and Jacks (2007) that industrialization might just as well have been carried out based on traditional energy carriers does not seem to be correct, not even in a country with ample forest resources like Sweden.

This argument is further strengthened when we look at the developments in each sub-period. Traditional energy played its most important role before the actual breakthrough of modern economic growth in Sweden around 1890. Between 1850 and 1870 traditional energy contributed $1.26 \%$ towards growth and modern energy only $0.07 \%$ p.a. Between 1870 and 1890 traditional energy still accounted for $0.81 \%$, while modern accounted for $0.22 \%$. The big change comes after 1890. Between 1890 and 1910 modern energy had passed traditional energy in importance and contributed $0.87 \%$ p.a., while traditional only accounted for $0.33 \%$. In the following decades, modern energy expanded its importance tremendously, while the contribution from traditional energy declined to zero or even small negative values. Our main conclusion is still that coal and modern energy in general mattered a lot for Swedish economic growth, especially from 1890 to 1950.

We can only speculate what would be the results if similar exercises were carried out for countries with very different factor endowments than Sweden. Naturally, traditional energy would play a much smaller role in England in this period. Coal already constituted $49 \%$ of energy use in England around 1700 and 77\% in 1800. By 1900, 95\% of energy used in England came from fossil fuels (Warde, 2007). For such a country, the contribution from modern energy to economic growth would naturally be much higher than the contribution from traditional energy. That we managed to demonstrate the importance of modern energy transition for a much more backward country that had to import most of its coal, only supports the general argument that the transition from traditional to modern energy was a necessary, albeit not sufficient, condition for industrialization. 


\section{References}

Acemoglu, Daron, “Directed Technical Change," Review of Economic Studies 69 (2002), 781-810.

Aitchison, J. and J. J. Egozcue, "Compositional Data Analysis: Where Are We and Where Should We Be Heading?” Mathematical Geology 37:7 (2005), 829-850.

Allen, Robert C., The British Industrial Revolution in Global Perspective (Cambridge: Cambridge University Press, 2009).

Arpi, G., Den Svenska Järnhanteringens Träkolsförsörjning 1830-1950 (Stockholm, 1951). Ayres, Robert U. and Benjamin Warr ,"Accounting for Growth: the Role of Physical Work," Structural Change and Economic Dynamics 16 (2005), 181-209.

Ayres, Robert U. and Benjamin Warr, The Economic Growth Engine: How Energy and Work Drive Material Prosperity (Cheltenham: Edward Elgar, 2009).

Berg, Charles A., "Process Innovation and Changes in Industrial Energy Use," Science 199 (1978), 608-614.

Berndt, Ernst R., Charles Kolstad, and J-K. Lee, "Measuring the Energy Efficiency and Productivity Impacts of Embodied Technical Change,” Energy Journal 14 (1993), 33-55. Bruns Stephan B., Christian Gross, and David I. Stern (in press) "Is There Really Granger Causality between Energy Use and Output?” Energy Journal.

Choi, In and Pentti Saikkonen, “Tests for Nonlinear Cointegration," Econometric Theory 26 (2010), 682-709.

Cipolla, Carlo M., The Economic History of World Population (London: Pelican Books, 1962).

Clark, Gregory and David Jacks, "Coal and the Industrial Revolution 1700-1869," European Review of Economic History 11 (2007), 39-72.

Cleveland Cutler J., Robert Costanza, Charles A. S. Hall and Robert K. Kaufmann, "Energy and the U.S. Economy: A Biophysical Perspective," Science 225 (1984), 890-897.

David, Paul A., "The Dynamo and the Computer: An Historical Perspective on the Modern Productivity Paradox," American Economic Review 80:2 (1990), 355-361.

Edvinsson, Rodney, Growth, Accumulation, Crisis: With New Macroeconomic Data for Sweden 1800-2000 (Stockholm: Almqvist \& Wiksell International, 2005). Fouquet, Roger, Heat, Power and Light: Revolutions in Energy Services (Cheltenham: Edward Elgar, 2008). 
Fouquet, Roger, "Divergences in Long-Run Trends in the Prices of Energy and Energy Services," Review of Environmental Economics and Policy 5:2 (2011), 196-218. Fröling, Maria, “Energy Use, Population and Growth, 1800-1970,” Journal of Population Economics 24:3 (2011), 1133-1163.

Gales, Ben, Astrid Kander, Paolo Malanima and Maria-del-Mar Rubio, "North versus South. Energy Transition and Energy Intensity in Europe over 200 Years," European Review of Economic History 11 (2007), 215-249.

Galor, O., Unified Growth Theory (Princeton NJ: Princeton University Press, 2011). Gancia, Gino and Fabrizio Zilibotti, "Horizontal Innovation in the Theory of Growth and Development," in Phillip Aghion and Stephen N. Durlauf, (eds.) Handbook of Economic Growth (Amsterdam: North Holland, 2005), Volume 1A 111-170.

Geijerstam, Jan af and Marie Nisser (eds.), Bergsbruk - Gruvor och Metallframställning (Sveriges Nationalatlas, 2011).

Goldin, Claudia and Lawrence F. Katz,The Race between Education and Technology (Cambridge, MA: The Belknap Press of Harvard University Press, 2008).

Hall, Charles Pradeep Tharakan, John Hallock, Cutler Cleveland, and Michael Jefferson, "Hydrocarbons and the Evolution of Human Culture," Nature 426 (2003), 318-322.

Harley, C. Knick and Nicholas F. R. Crafts, "Simulating the Two Views of the British Industrial Revolution,” Journal of Economic History 60 (2000), 819-841.

Hassler, John, Per Krusell, and Conny Olovsson, “Energy-Saving Technical Change,” NBER Working Paper 18456 (2012).

Henriques, Sofia T., "Energy Transitions, Economic Growth and Structural Change: Portugal in a Long-Run Comparative Perspective," Lund Studies in Economic History 54 (2011).

Hong, Seung H. and Martin Wagner, "Nonlinear cointegration analysis and the environmental Kuznets curve," Economics Series, Institute for Advanced Studies, Vienna 224 (2008).

Hughes, Thomas P., Networks of Power, Electrification in Western Society, 1880-1930 (London: The John Hopkins University Press, 1983).

Iriarte-Goñi, Inaki and Maria I. Ayuda, "Wood and Industrialization: Evidence and Hypotheses from the Case of Spain, 1860-1935," Ecological Economics 65 (2008), 177186. 
Iriarte-Goñi, I. and M. I. Ayuda, "Not Only Subterranean Forests: Wood Consumption and Economic Development in Britain, (1850-1938)," Ecological Economics 77 (2012), 176184.

Kaijser, A. and Astrid Kander, Framtida Energiomställningar i Historiskt Perspektiv, Naturvårdsverkets Rapportserie (2013).

Kander, Astrid "Economic Growth, Energy Consumption and $\mathrm{CO}_{2}$ Emissions in Sweden 1800-2000," Lund Studies in Economic History 19 (2002).

Kander, Astrid and Paul Warde, (2009) "Number, Size and Energy Consumption of Draught Animals in European Agriculture," Centre for History and Economics Working Paper, http://www.histecon.magd.cam.ac.uk/history-sust/animals.htm (2005).

Kander, Astrid and Paul Warde "Energy Availability from Livestock and Agricultural Productivity in Europe, 1815-1913: A New Comparison," Economic History Review 64:1 (2011), 1-29.

Kander, Astrid, Paolo Malanima, and Paul Warde, Power to the People - Energy and Economic Transformation of Europe over Four Centuries (Princeton: Princeton University Press, 2013).

Kim, H. Youn, “The Translog Production Function and Variable Returns to Scale," Review of Economics and Statistics 74 (1992), 546-552.

Krantz, Olle and Lennart Schön, "Swedish Historical National Accounts 1800-2000," Lund Studies in Economic History 41 (2007).

Kwiatkowski, Denis, Peter C. B. Phillips, Peter Schmidt, and Yongcheol Shin, "Testing the Null Hypothesis of Stationarity against the Alternative of a Unit Root," Journal of Econometrics 54 (1992), 159-178.

Kunnas, Jan and Timo Myllyntaus, "Postponed Leap in Carbon Dioxide Emissions: the Impact of Energy Efficiency, Fuel Choices and Industrial Structure on the Finnish Economy 1800-2005," Global Environment 3 (2009), 154-189.

Leon-Ledesma, Miguel A., Peter McAdam, and Alpo Willman, "Identifying the Elasticity of Substitution with Biased Technical Change," American Economic Review 100 (2010), 1330-1357.

Madsen, Jakob B., James B. Ang, and Rajabrata Banerjee,) "Four Centuries of British Economic Growth: the Roles of Technology and Population," Journal of Economic Growth 15:4 (2010), 263-290. 
Malanima, Paolo, Energy Consumption in Italy in the 19th and 20th Centuries (Napoli: ISSM-CNR, 2006).

Mayumi, Kozo, “Temporary Emancipation from Land: from the Industrial Revolution to the Present Time," Ecological Economics 4 (1991), 35-56.

Mokyr, Joel, “The Second Industrial Revolution, 1870-1914,” In: V.Castronovo, (ed.) Storia dell'Economia Mondiale (Rome: Laterza, 1999).

Newey, Whitney K and Kenneth D. West, “A Simple, Positive Semi-Definite, Heteroskedasticity and Autocorrelation Consistent Covariance Matrix," Econometrica 55:3(1987), 703-708.

O’Mahony, Mary and Marcel P. Timmer, "Output, Input and Productivity Measures at the Industry Level: the EU KLEMS Database”, Economic Journal 119 (2009), F374-F403.

Petith, Howard, "Land, Technical Progress and the Falling Rate of Profit," Journal of Economic Behavior and Organization 66 (2008), 687-702.

Pomeranz, Kenneth, The Great Divergence. Europe, China, and the Making of the Modern World Economy (Princeton: Princeton University Press, 2000).

Rubio, Maria -del-Mar “Economía, Energía y $\mathrm{CO}_{2}$ : España 1850-2000,” Cuadernos Economicos de ICE 70 (2005).

Saunders, Harry D., “The Khazzoom-Brookes Postulate and Neoclassical Growth,” Energy Journal 13:4 (1992), 131-148.

Schön, Lennart, Trädbränslen i Sverige 1800-1990 - Användning och Prisutveckling (Vattenfall, 1992).

Schön, Lennart, An Economic History of Modern Sweden (London: Routledge, 2012).

Smil, Vaclav, Energy In World History (Boulder CO: Westview Press, 1994).

Smil, Vaclav, Creating the Twentieth Century, Technical Innovations of 1867-1914 and Their Lasting Impact (New York: Oxford University Press, 2005).

Smil, Vaclav, Prime Movers of Globalization, The History and Impact of Diesel Engines and Gas Turbines (London: The MIT Press, 2010).

Solow, Robert M., “A Contribution to the Theory of Economic Growth,” Quarterly Journal of Economics 70 (1956), 65-94.

Stern, David I., ‘Energy Quality,” Ecological Economics 69:7 (2010), 1471-1478.

Stern, David I. and Kerstin Enflo, "Causality between Energy and Output in the Long-Run," Energy Economics 39 (2013), 135-146.

Stern, David I. and Astrid Kander, "The Role of Energy in the Industrial Revolution and 
Modern Economic Growth,” Energy Journal 33:3 (2012), 127-154.

Temin, Peter, "Two Views of the British Industrial Revolution,” Journal of Economic History 53 (1997), 63-82.

Warde, Paul, Energy Consumption in England and Wales 1560-2000 (Napoli: ISSMCNR, 2007).

Wilkinson, Richard G., Poverty and Progress: An Ecological Model of Economic Development, London: Methuen (1973).

Wrigley, E. Anthony, "The Supply of Raw Materials in the Industrial Revolution," Economic History Review 15 (1962), 1-16.

Wrigley, E. Anthony, Continuity, Chance, and Change: The Character of the Industrial Revolution in England (Cambridge: Cambridge University Press, 1988).

Wrigley, E. Anthony, Energy and the English Industrial Revolution (Cambridge: Cambridge University Press, 2010). 
Table 1. Levels of Key Variables at 20 Year Intervals 1850-1950.

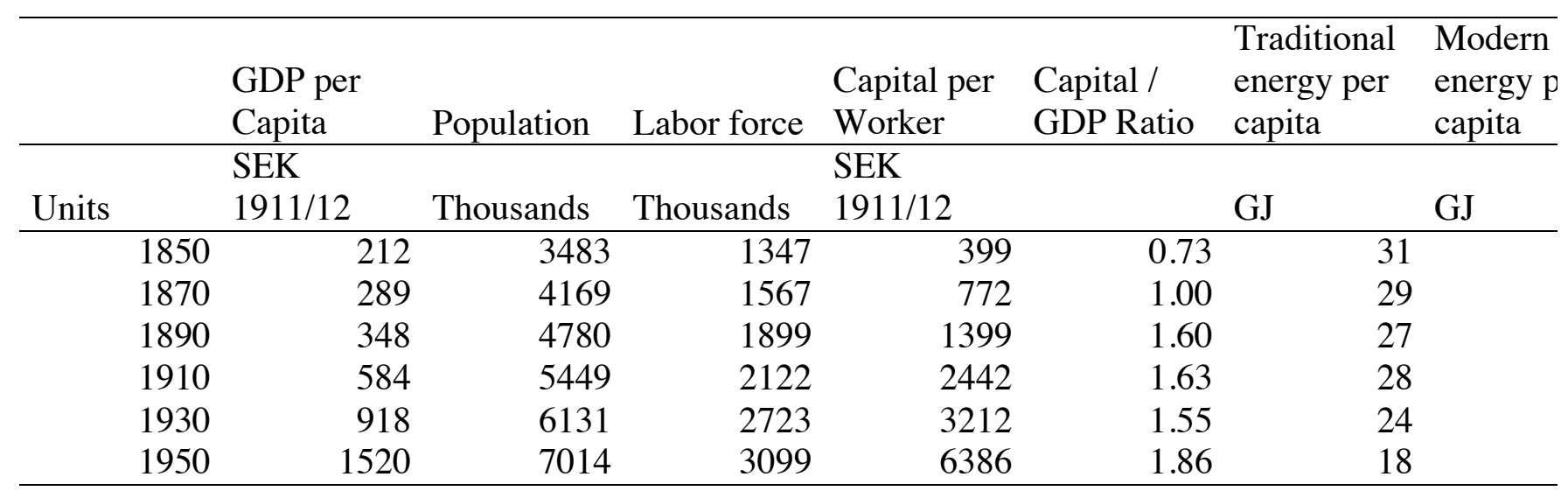

Table 2. Average Annual Growth Rates of Key Variables Over 20-year periods and 1850-1950

\begin{tabular}{lllllll}
\hline & $\begin{array}{l}\text { GDP per } \\
\text { Capita }\end{array}$ & Population & Labor force & $\begin{array}{l}\text { Capital per } \begin{array}{l}\text { Traditional } \\
\text { energy per } \\
\text { capita }\end{array} \\
\text { Modern } \\
\text { energy per } \\
\text { capita }\end{array}$ \\
\hline $1850-1870$ & $1.6 \%$ & $0.9 \%$ & $0.8 \%$ & $3.4 \%$ & $-0.2 \%$ & $7.9 \%$ \\
$1870-1890$ & $0.9 \%$ & $0.7 \%$ & $1.0 \%$ & $3.0 \%$ & $-0.4 \%$ & $6.1 \%$ \\
$1910-1910$ & $2.6 \%$ & $0.7 \%$ & $0.6 \%$ & $2.8 \%$ & $0.2 \%$ & $4.7 \%$ \\
$1930-1950$ & $2.3 \%$ & $0.6 \%$ & $1.3 \%$ & $1.4 \%$ & $-0.8 \%$ & $1.6 \%$ \\
$1850-1950$ & $2.6 \%$ & $0.7 \%$ & $0.6 \%$ & $3.5 \%$ & $-1.4 \%$ & $2.5 \%$ \\
\hline
\end{tabular}


Table 3. Econometric Results

\begin{tabular}{llll}
\hline \multicolumn{5}{c}{ Parameter Estimates } \\
\hline$\gamma_{E}$ & $\begin{array}{l}0.1693 \\
(0.0064)\end{array}$ & $\tau_{M 1}$ & 0.0239 \\
& & & $(0.0116)$ \\
$\gamma_{B}$ & 0.7464 & $\tau_{L 1}$ & 0.0099 \\
& $(0.0061)$ & & $(0.0017)$ \\
$\gamma_{Y}$ & 0.9975 & $\tau_{B 2}$ & -0.00019 \\
& $(0.0195)$ & & $(0.00006)$ \\
$\phi$ & -0.5425 & $\tau_{M 2}$ & -0.00047 \\
& $(0.2937)$ & & $(0.00009)$ \\
$\omega$ & 0.7750 & $\tau_{L 2}$ & 0.00015 \\
& $(0.0918)$ & & $(0.00002)$ \\
$\tau_{B 1}$ & 0.0136 & & \\
& $(0.0057)$ & & \\
\hline
\end{tabular}

Robust standard errors in parentheses

Residual Non-Stationarity Test

\begin{tabular}{ll}
\hline Dependent Variable & Choi and Saikkonen Test Statistic \\
\hline $\ln \left(S_{L} / S_{B}\right)$ & 0.5769 \\
$\ln \left(S_{B} / S_{M}\right)$ & 0.2641 \\
$\ln Y$ & 0.6825 \\
\hline
\end{tabular}

Critical values: 2.421 at the $5 \%$ level and 1.934 at the $10 \%$ level (Hong and Wagner, 2008). 
Table 4. Growth Accounting

\begin{tabular}{lllllll}
\hline & \multicolumn{5}{c}{ Contributions to Annual Rate of Growth } \\
\hline Factor & $1850-$ & $1870-$ & $1890-$ & $1910-$ & $1930-$ & $1850-$ \\
& 1870 & 1890 & 1910 & 1930 & 1950 & 1950 \\
\hline $\begin{array}{l}\text { Traditional Energy } \\
\text { Traditional Energy }\end{array}$ & $0.23 \%$ & $0.08 \%$ & $0.14 \%$ & $-0.03 \%$ & $0.00 \%$ & $0.09 \%$ \\
$\begin{array}{l}\text { Quality } \\
\text { Traditional Energy }\end{array}$ & $-0.04 \%$ & $0.08 \%$ & $-0.11 \%$ & $-0.06 \%$ & $-0.11 \%$ & $-0.05 \%$ \\
$\begin{array}{l}\text { Augmenting } \\
\text { Technology }\end{array}$ & $1.07 \%$ & $0.65 \%$ & $0.30 \%$ & $0.07 \%$ & $0.00 \%$ & $0.42 \%$ \\
Modern Energy & $0.04 \%$ & $0.13 \%$ & $0.32 \%$ & $0.34 \%$ & $0.58 \%$ & $0.28 \%$ \\
$\begin{array}{l}\text { Modern Energy } \\
\text { Quality }\end{array}$ & $0.00 \%$ & $0.01 \%$ & $0.41 \%$ & $0.39 \%$ & $0.45 \%$ & $0.25 \%$ \\
$\begin{array}{l}\text { Modern Energy } \\
\text { Augmenting }\end{array}$ & & & & & & \\
$\begin{array}{l}\text { Technology } \\
\text { Capital }\end{array}$ & $0.03 \%$ & $0.08 \%$ & $0.14 \%$ & $0.06 \%$ & $-0.21 \%$ & $0.02 \%$ \\
$\begin{array}{l}\text { Labor } \\
\text { Labor Augmenting }\end{array}$ & $0.61 \%$ & $0.62 \%$ & $0.57 \%$ & $0.47 \%$ & $0.73 \%$ & $0.60 \%$ \\
Technology & $0.38 \%$ & $0.52 \%$ & $0.32 \%$ & $0.76 \%$ & $0.40 \%$ & $0.48 \%$ \\
\hline $\begin{array}{l}\text { Predicted GDP } \\
\text { Actual GDP }\end{array}$ & $-0.10 \%$ & $0.21 \%$ & $0.56 \%$ & $0.94 \%$ & $1.30 \%$ & $0.58 \%$ \\
\begin{tabular}{l} 
Residual \\
\hline
\end{tabular} & $2.24 \%$ & $2.39 \%$ & $2.63 \%$ & $2.95 \%$ & $3.13 \%$ & $2.67 \%$ \\
\hline
\end{tabular}


Figure 1. Per Capita Energy Use in Europe 1500-2000 GJ

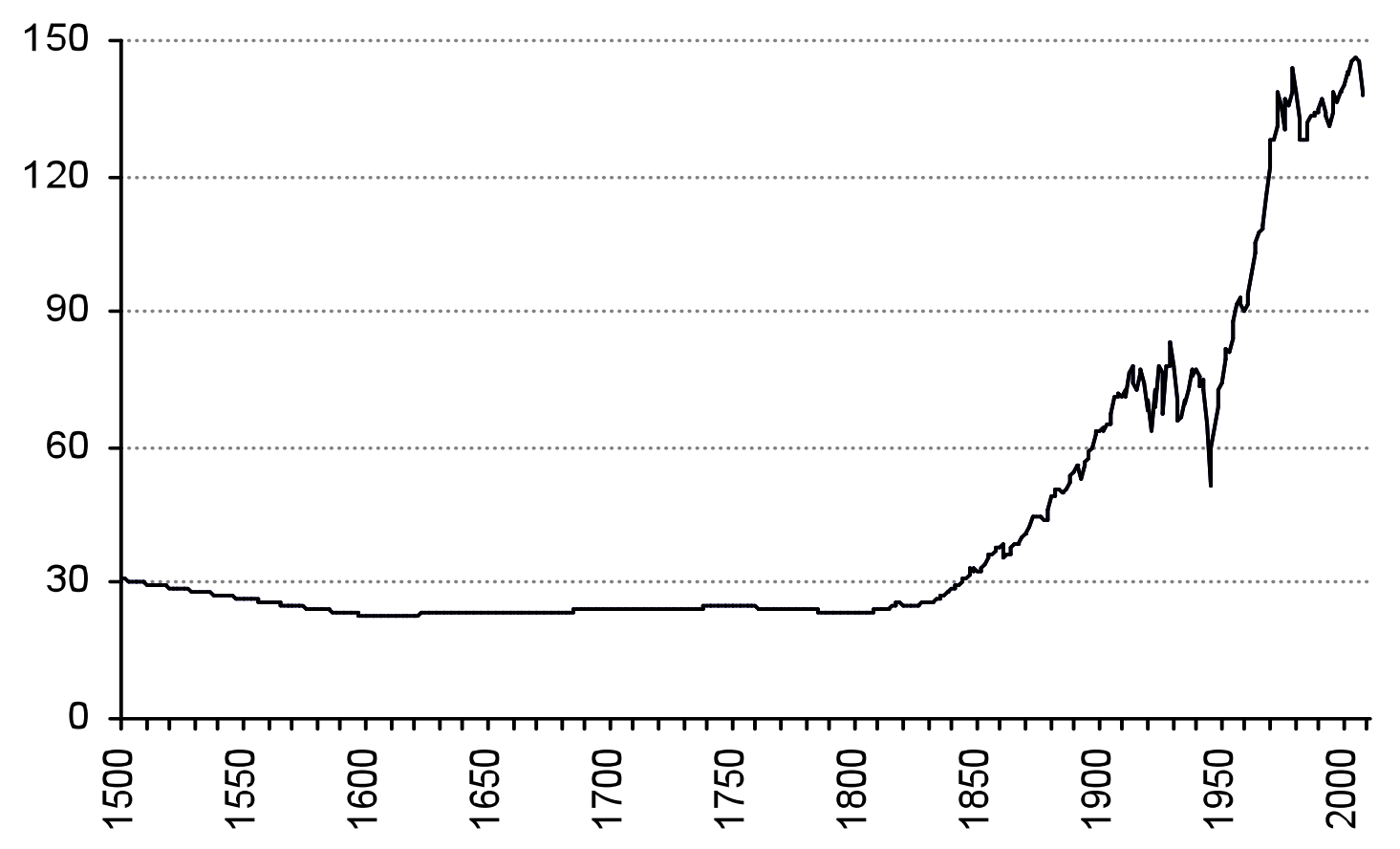

Source: Kander et al. (2013) 
Figure 2. Energy per Capita, GJ per Annum in Sweden, England, and Europe

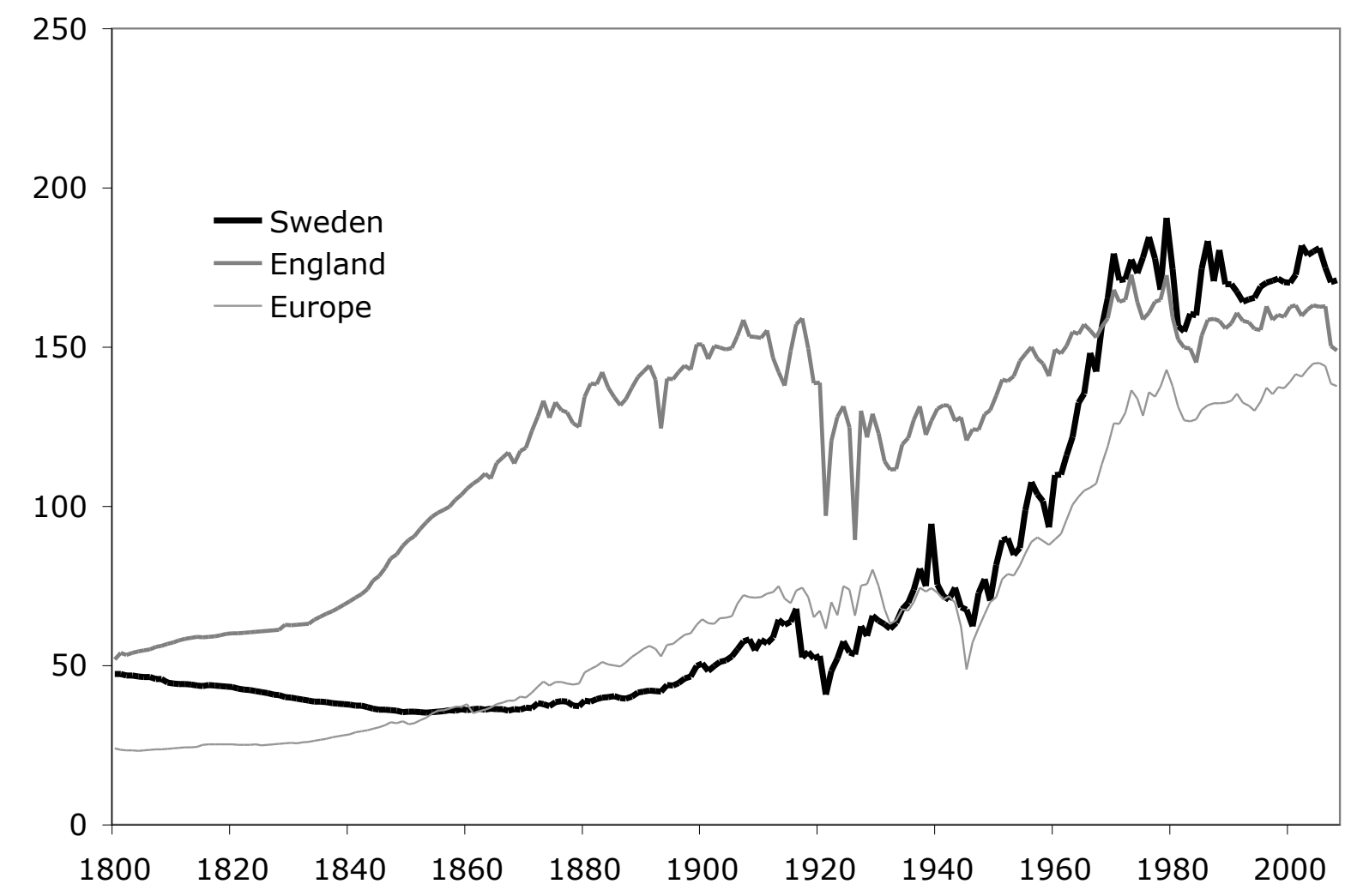

Source: Kander et al. (2013), see www.energyhistory.org 
Figure 3. Share of Coal in Total Energy Consumption in Eight European Countries 1800-1913

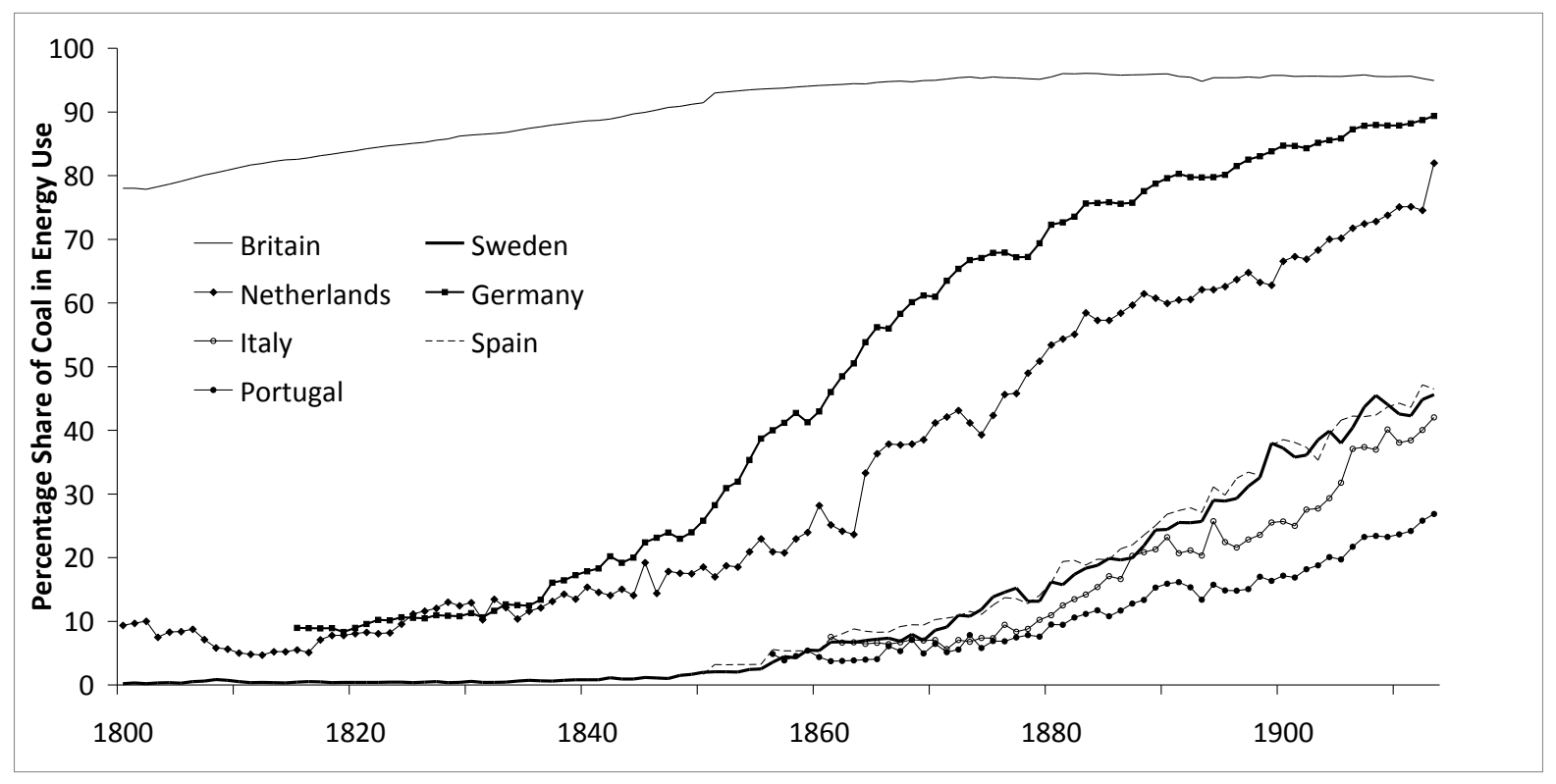


Figure 4. Heat Shares of Traditional and Modern Energy Carriers

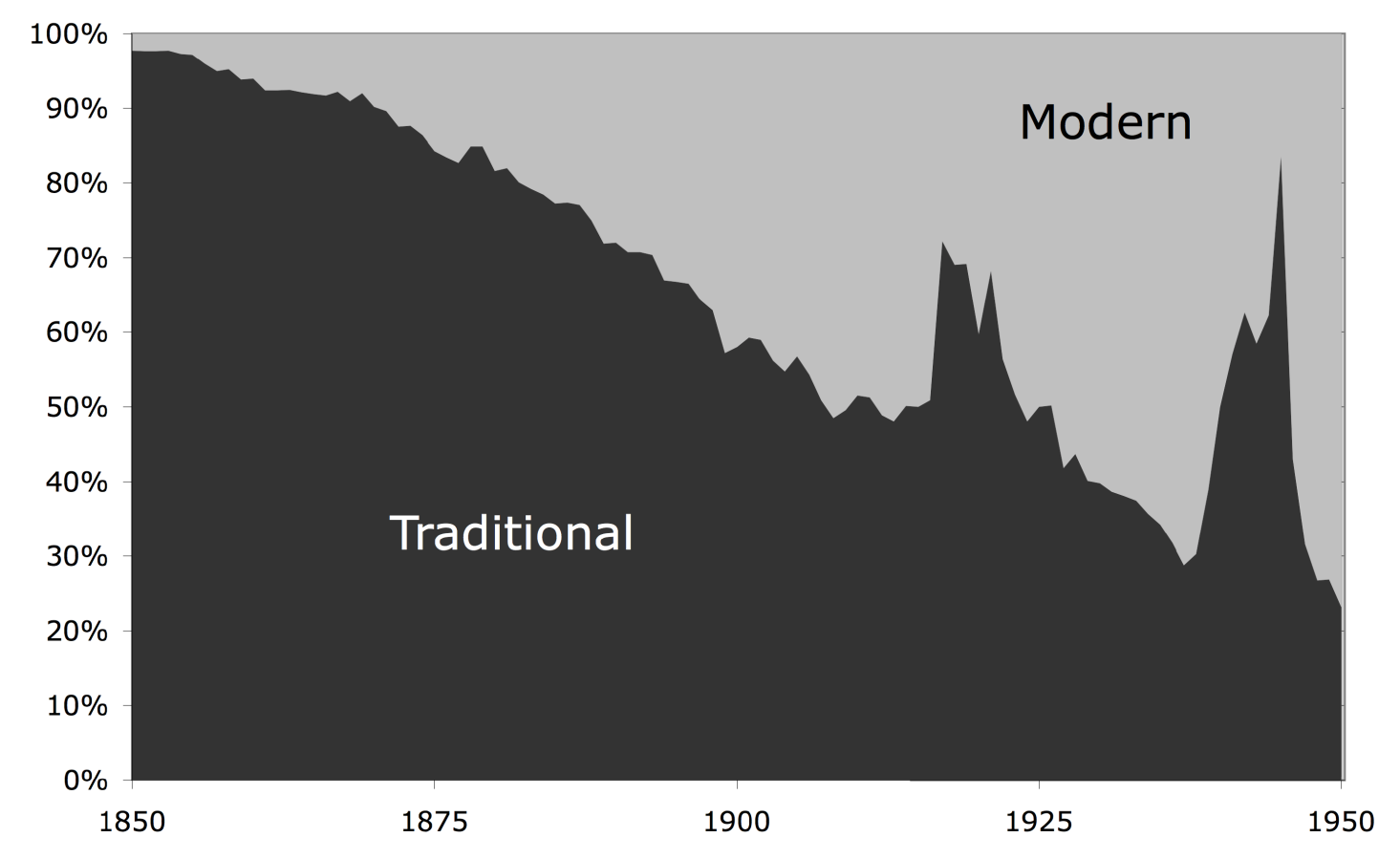


Figure 5. Cost Shares of Traditional and Modern Energy Carriers

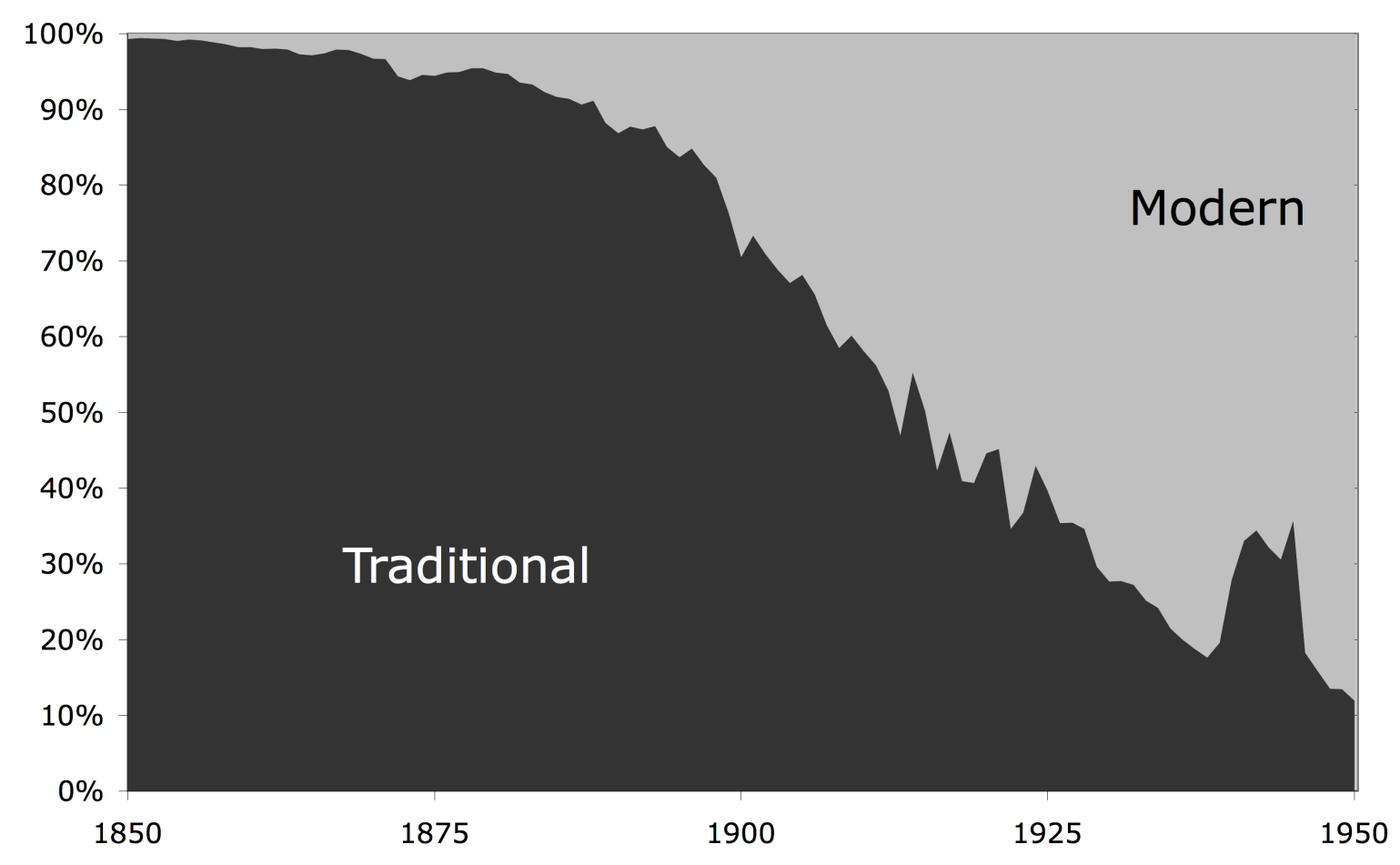


Figure 6. Real Energy Prices

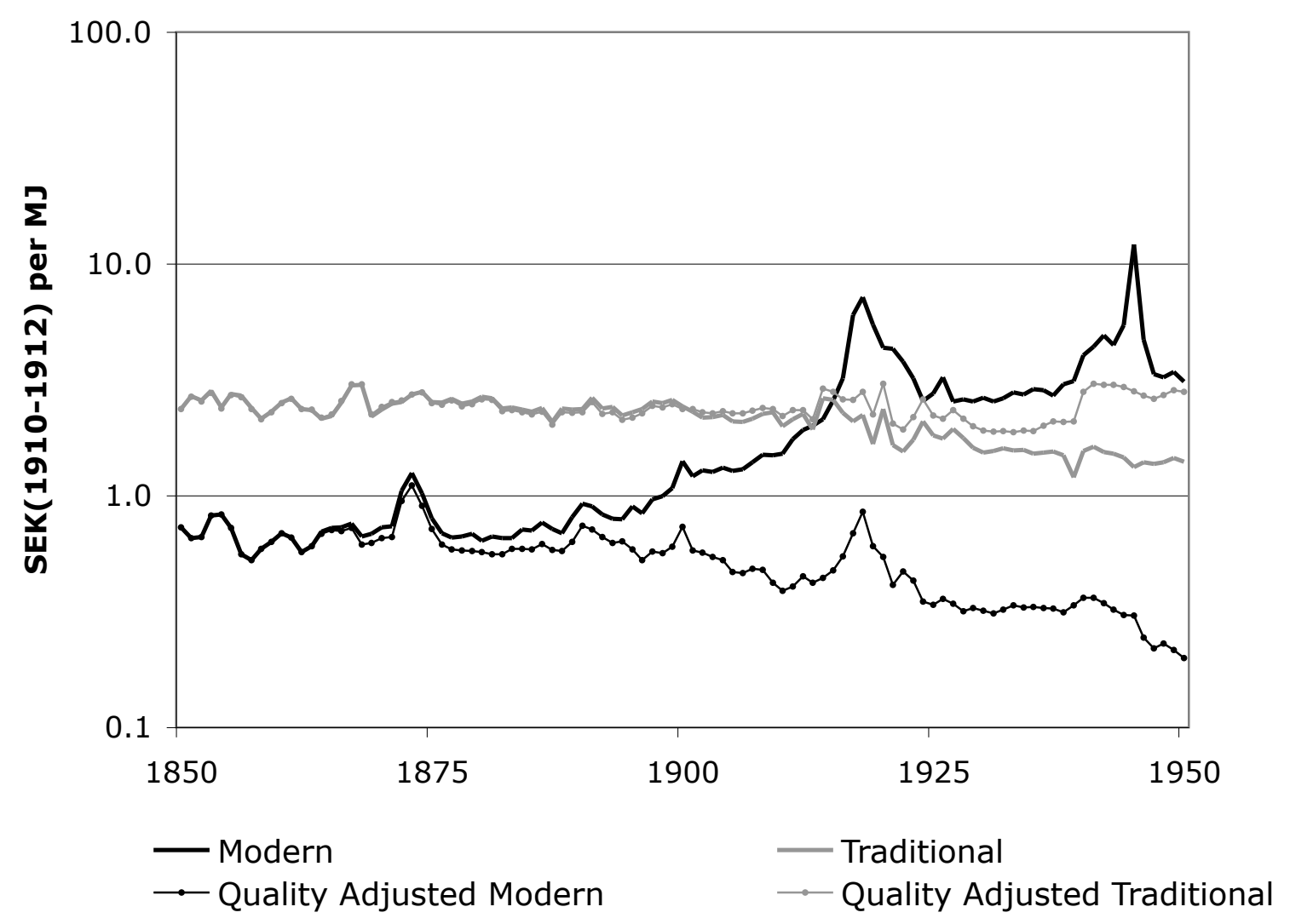

